\title{
Bernard Forest de Bélidor: Engineer, Manualist and Machine Historian
}

\author{
Luigi Traetta \\ Department of Humanities, University of Foggia, Foggia, Italy \\ Email: luigi.traetta@unifg.it
}

How to cite this paper: Traetta, L. (2020). Bernard Forest de Bélidor: Engineer, Manualist and Machine Historian. Advances in Historical Studies, 9, 70-83.

https://doi.org/10.4236/ahs.2020.92006

Received: May 11, 2020

Accepted: June 27, 2020

Published: June 30, 2020

Copyright $\odot 2020$ by author(s) and Scientific Research Publishing Inc. This work is licensed under the Creative Commons Attribution International License (CC BY 4.0).

http://creativecommons.org/licenses/by/4.0/

\begin{abstract}
The establishment of mechanical engineering during the Industrial Revolution produced, among other things, the birth of technical manuals, accompanied by a significant increase in historical studies of the machines of the past. This article examines the work of Bernard Forest de Bélidor (1698-1761) in the light of current historiographic trends, which, on the one hand, identify the Renaissance as the period of the encounter between science and technology and, on the other, highlight the lack of descriptive documents on the machines of time. A solider, mathematician and member of several scientific academies, Bélidor is one of the very few historians of Renaissance machines, as well as an engineer in the most modern sense of the term and a precise model designer. In the manuals written for his lectures at the French School of Artillery, he also proved capable of a courageous attempt to apply Newtonian mathematics and physics to machines, anticipating by half a century the process of scientication of technology that would later ratify the birth of rational mechanics.
\end{abstract}

\section{Keywords}

Bernard Forest de Bélidor, History of Machines, History of Hydraulic Technology

\section{Introduction}

In his classic work, A History of Technology, which first appeared in 1957, Usher highlighted the difficulties faced by historians in the task of reconstructing the development of Renaissance machines, due to the lack of descriptive sources. Although numerous diagrams and designs of the time are easily available, documents on the details of the operation of mechanisms and toolssources that would allow a complete history of the machines of the $16^{\text {th }}$ and $17^{\text {th }}$ centuries to be written for the first time-are extremely rare, apart from a couple 
of exceptions.

The two main exceptions are Agricola's De re metallica (1556) and Architecture hydraulique by Bélidor, who, to describe the methods of managing water for civil use in the mid- $18^{\text {th }}$ century, focused at length on the construction details of mechanisms connected with the operation of hydraulic pumps from the $15^{\text {th }}-16^{\text {th }}$ century. "Belidor's work," continues Usher, "is probably one of the most significant indications we have of the limits of engineering skills at this time, but it has as yet been too little studied" (Usher, 1957: p. 334).

Critical literature on Bélidor is still very rare, just as the multiple facets of his learning remain rather unknown. The aim of this essay, therefore, is the reconstruction of Bélidor's scientific biography and the rereading of his major worksparticularly Architecture hydraulique-from which emerges a surprising passion for the history of machines and an unrelenting accusation of Renaissance mechanics for having completely neglected the not-so-remote origins of their subject.

\section{An Engineering Mathematician}

Born in Catalonia in 1697 and very soon orphaned of both parents, Bernard Forest de Bélidor was brought up in France by the spouses De Fossiébourg and introduced to an interest in mathematics by his adoptive mother's brother, the engineer Cayot de Blanzy. It was under his charge, while directly involved in the siege of Bouchain and Quesnoy, that the very young Bélidor had the opportunity to discover the connection between the theoretical aspects of mathematics and their practical application to artillery operations and military engineering, particularly in the fortification of territory and the graphic representation of fields (Académie des sciences, 1783, 1788).

After collaborating with Cassini and de la Hire on the definition of the Paris meridian, Bélidor, who in the meantime had become acquainted with the Minister le Blanc and the Duke of Orleans, was appointed professor of mathematics at the artillery school in La Fère. In 1720 he published Sommaire d'un cours d'architecture militaire, civil, hydraulique and, in 1725, his first successful work, Nouveau cours de mathématique. Although this was apparently intended to "make maths interesting", particularly when applied to the "fields of engineering and artillery" (Bélidor, 1725: p. III), it also contained, among other things, a discussion of complex machines and several detailed descriptions of hydraulic pumps.

Having addressed mechanics, particularly in the ninth and tenth parts of the manual, Bélidor wrote by way of introduction, "It is the science of building machines and using them to lift heavy weights" (ibid.). Thus, in the Nouveau Cours, we should not expect a discussion of the constructional details of the machines of the time, but rather an in-depth study of topics connected with the application of mathematical analysis to Newtonian physics. In short, it is a summary of rational mechanics, which nevertheless foreshadowed the typically 
late-eighteenth-century trend of the "scientication" of technology, consequent to the diffusion of machines. In addition to the description of so-called "simple" machines (the lever, the wheel on its axle, the pulley, the inclined plane, the wedge and the screw), explanations are also found on the operation of some complex machines (Figure 1) used for military purposes, in the construction of fortifications, artillery operations and the transport of weapons and ammunition by ship.

The great fame resulting from the Nouveau Cours, both in France and abroad, enabled Bélidor to obtain the rank of Artillery Commissaire. Then, in 1729, he published the Science des Ingénieurs, a true continuation of the ideas in the 1720 essay on military architecture. Among the new topics in relation to the past, mention must certainly be made of the techniques for choosing materials suitable for fortification works and of the mathematical models for determining the appropriate payment for labourers engaged in various tasks-a rather delicate matter, given that wage recriminations by unskilled workers would often end up

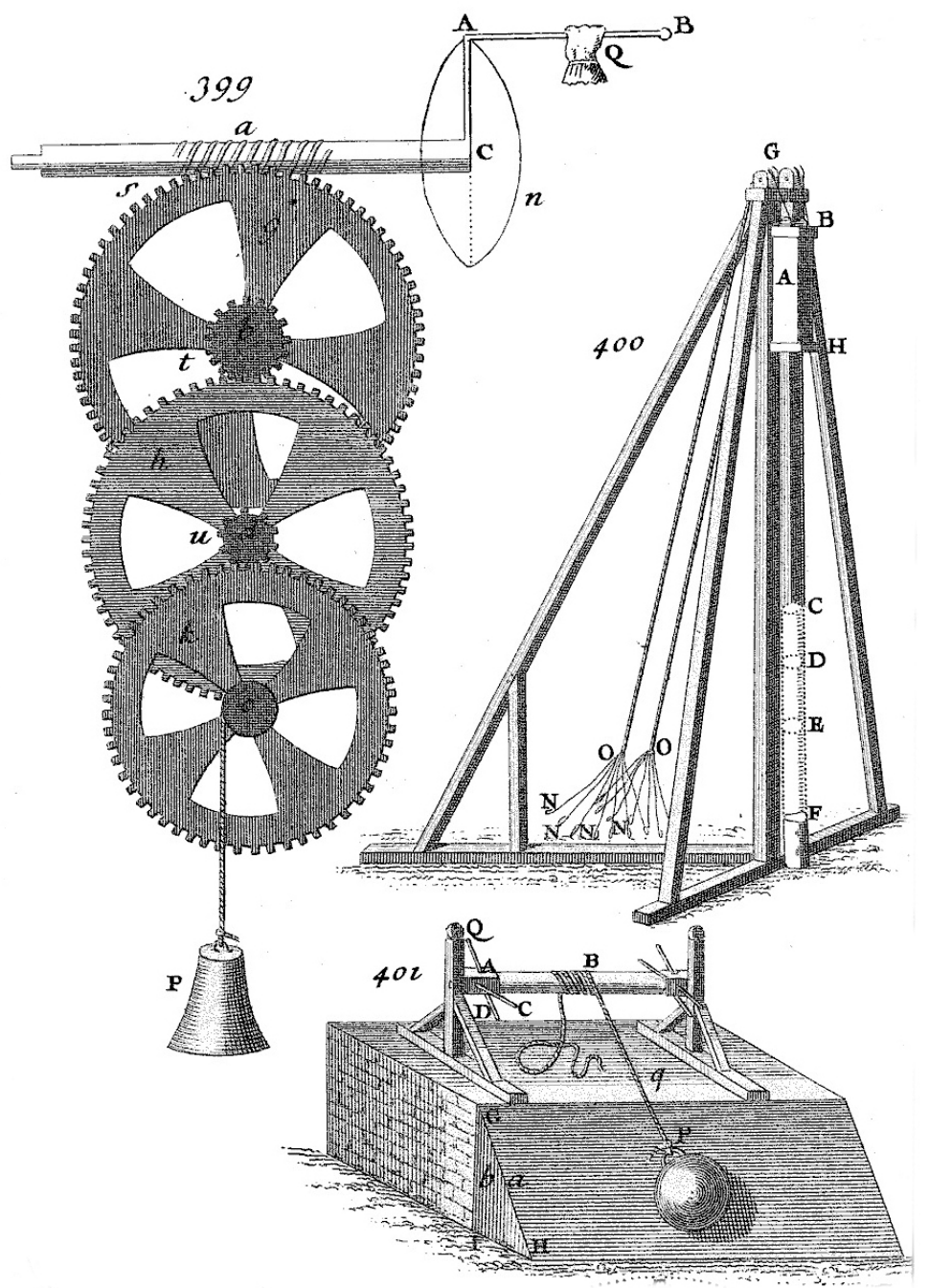

Figure 1. Some examples of complex machines presented by Bélidor. 
putting the architect in difficulty. However, Bélidor was not the first to address this issue. In 1688, the military engineer Sébastien la Prestre de Vauban (16331707) - mentioned in the Science des Ingénieurs—had already produced proper regulations, with a set of guidelines to be followed, in an attempt to resolve the problem of workers' protests over wages paid for particularly arduous work. Vauban's ideas once more proved to be a source of inspiration for Bélidor when, in his Architecture hydraulique, he had to account for the time required to carry out individual tasks in complex work, such as driving piles into the ground.

In 1731, in Les bombardier françois - an essay that would soon become the official manual in all French artillery schools-Bélidor (1731) further examined the link between ballistics and mathematics by reporting, among other things, the firing tests performed at end of April of the same year with the La Perrelle Royal Battalion.

In 1733, the Minister of War, d'Angervilliers, appointed him to a secret commission assigned to draft guidelines for French foreign policy and, in 1737, Bélidor (1737) published the first part of his Architecture hydraulique. This was subsequently followed by the other two parts, in 1750 and 1753 respectively. In the meantime, however, due to a dispute with the Prince of Dombes, the Grand Master of Artillery, over the methods of calculating the most effective charge quantities for shooting with firearms-a "classic" ballistics topic of the time-he was dismissed from all his assignments.

Despite flattering invitations from various foreign powers to transfer to their service, Bélidor remained faithful to France and in 1742 Marshal de Belle-Isle had him appointed captain. After the campaigns in Bavaria and Bohemia, where he was also taken prisoner, he participated, with the rank of lieutenant colonel, in the campaign in Italy, where he distinguished himself for calculating the time and quantity of mines necessary to demolish the fortress in Demonte.

Appointed colonel, he returned after the peace treaty of Aachen to take up full-time research, becoming, among other things, a member of the Parisian Academy of Sciences on 31 March 1756, Inspector of the Paris Arsenal in 1758 and Inspector-General of the Royal Corps of Miners of France in 1759. In the same year, as if to express all his gratitude towards the family that had adopted him, he married their daughter, also entitling her to a share in the substantial wealth from the pension he was granted. Weakened by a stroke and by the efforts sustained during a mission conducted in Verdun as Inspector of the Corps of Minors, Bélidor died in Paris on 8 September 1761.

\section{The Historiographer Engineer}

In the introduction to Volume I, Book II of Architecture hydraulique, intending to justifying himself to the reader for a lengthy digression on the operation of water mills, a technology widely used in the first half of the eighteenth century, Bélidor stated: "It may seem strange that I endeavour to write on a subject as well known as this, but an examination of the reasons that led me to compose 
this chapter will reveal several that justify me" (Bélidor, 1737: p. 277). One of the principal reasons he gave, the universality of hydraulic energy, should certainly be mentioned since, in the early part of the 18th century, it was still the only source of alternative energy to human or animal muscle power (Viollet, 2005: p. 9). Hence, the importance of applying the principles of mechanics to mills, with the aim of making their operation as efficient as possible.

In 1739, two years after the publication of the first volume, Bélidor gave the printers the second part of Architecture hydraulique, the third book of which discussed machines that harnessed the expansion and condensation of air, and introduced the physical and mechanical laws underlying the operation of pumps. In particular, the fourth chapter described the most notable machines invented to raise water and the fifth chapter presented a genuine history, tracing the development of hydraulic pumps since the time of the ancient Romans.

Pumps were first of all classified, in accordance with tradition, into sucking and pushing devices. The former were useful when water had to be raised from a deep place, while the latter were used to force water upwards through vertical pipes. Very often, however, systems would use a combination of both machines.

The traditional suction pump model (Figure 2) nevertheless had numerous design variations. Bélidor began with the model (Figure 3 ) with a handle operated by one or more men, perfected by Morel, who, "instead of using three or

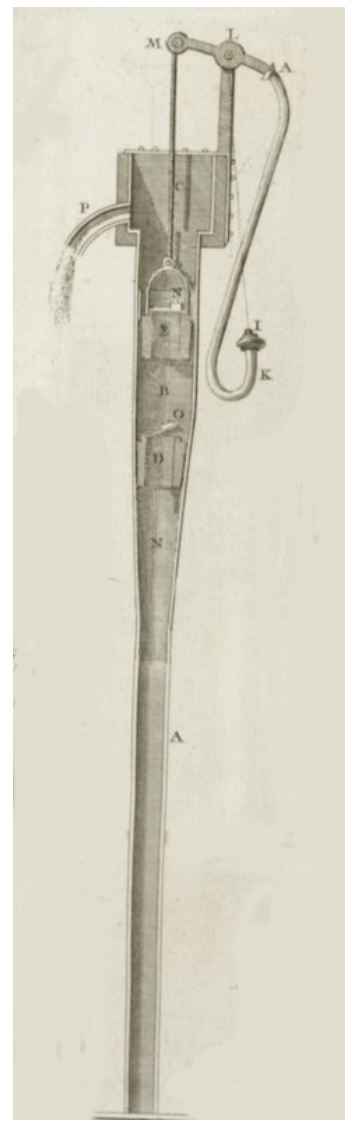

Figure 2. Traditional model of a suction pump. 
four men, as is normally done to move large hanging bells," had the idea of using only one, concentrating the "force with a foot on the end of a plank connected to the water ram" (Bélidor, 1739: p. 132) (Figure 4).

The problem of how to put the complex mechanisms of which the pumps were composed into motion was as important as the general design of the machine. Already towards the mid- $16^{\text {th }}$ century, the German, Georg Bauer, better known as Giorgius Agricola, had described the mechanical problems in water lifting processes, highlighting the fact that machines equipped with a bucket-chain

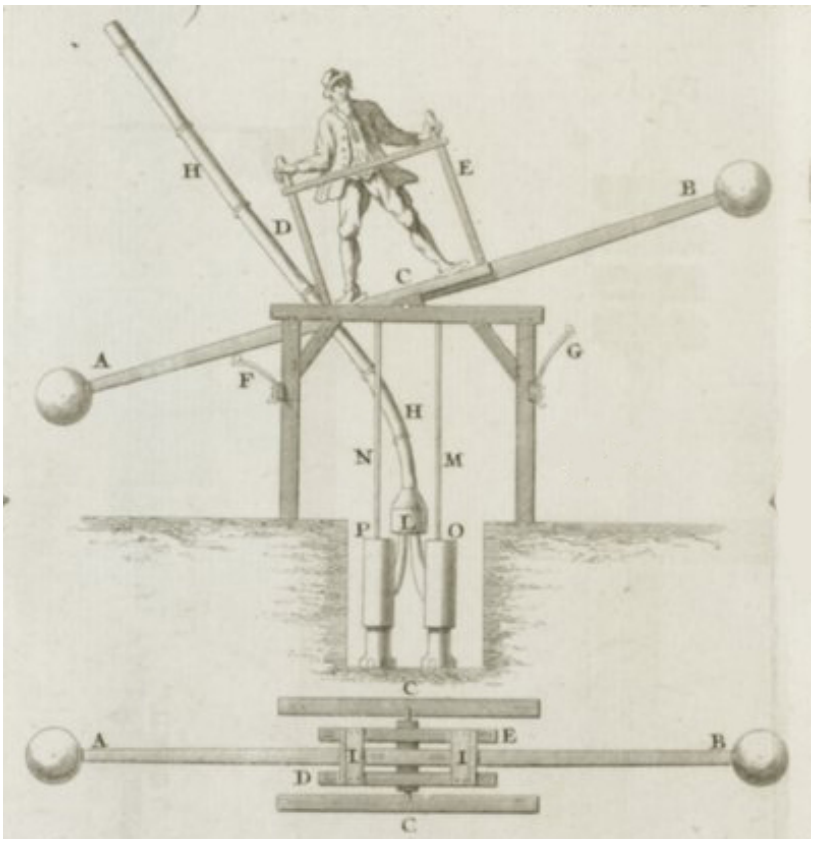

Figure 3. Suction pump with lever.

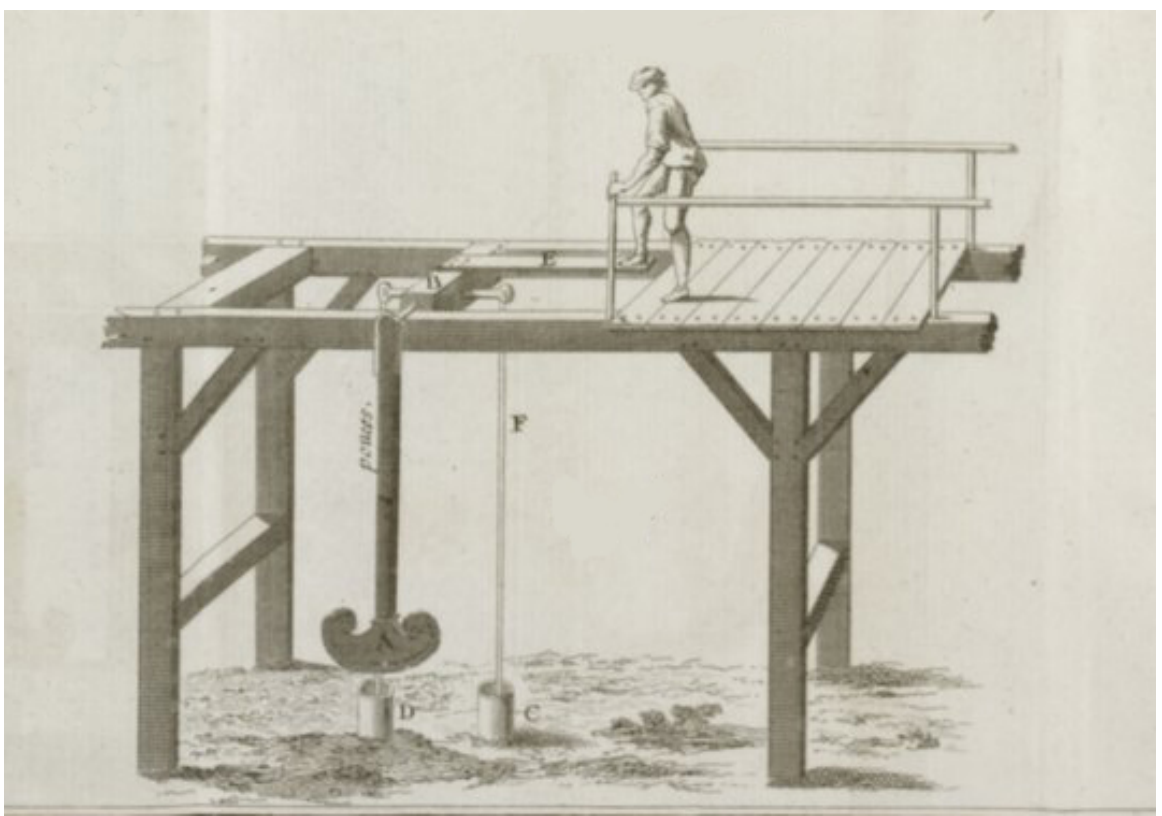

Figure 4. Morel lever pump. 
(Figure 5), particularly common in the 1500 s and almost always set in motion by human effort, proved rather fragile when used with a hydraulic driving force.

For purposes that were also "didactic and descriptive" (Beretta, 2017: p. 100), Agricola provided an accurate description of the operation of piston pumps using an abundant collection of woodcuts. Composed essentially of several pipes assembled together up to the desired height, and a piston with some kind of valve to prevent the raised water from returning downwards, these machines, driven by a water wheel, had a yield about ten times greater than those powered by human effort.

The models mentioned, however, were all subsequent to a machine designed by Leonardo da Vinci in around 1500, based on two fundamental principles that would also be found in the more complex pumps of the following decades. An initial Archimedes' screw raised the water to an intermediate tank, from where a second screw brought it to a collection tank at an even greater height; both screws were driven by a water wheel located in the river, at the same point where the water was drawn. Leonardo had therefore understood the importance of creating intermediate tanks and of using the power of the water itself to operate the pumps (Figure 6).

The seventh type of machine in Agricola's classification had three pumps arranged in series, with only the first of them immersed in the well. This pumped the water up and emptied it into a tank connected to the second pump, which, in turn sucked up the water and sent it to the third pump, which finally emptied

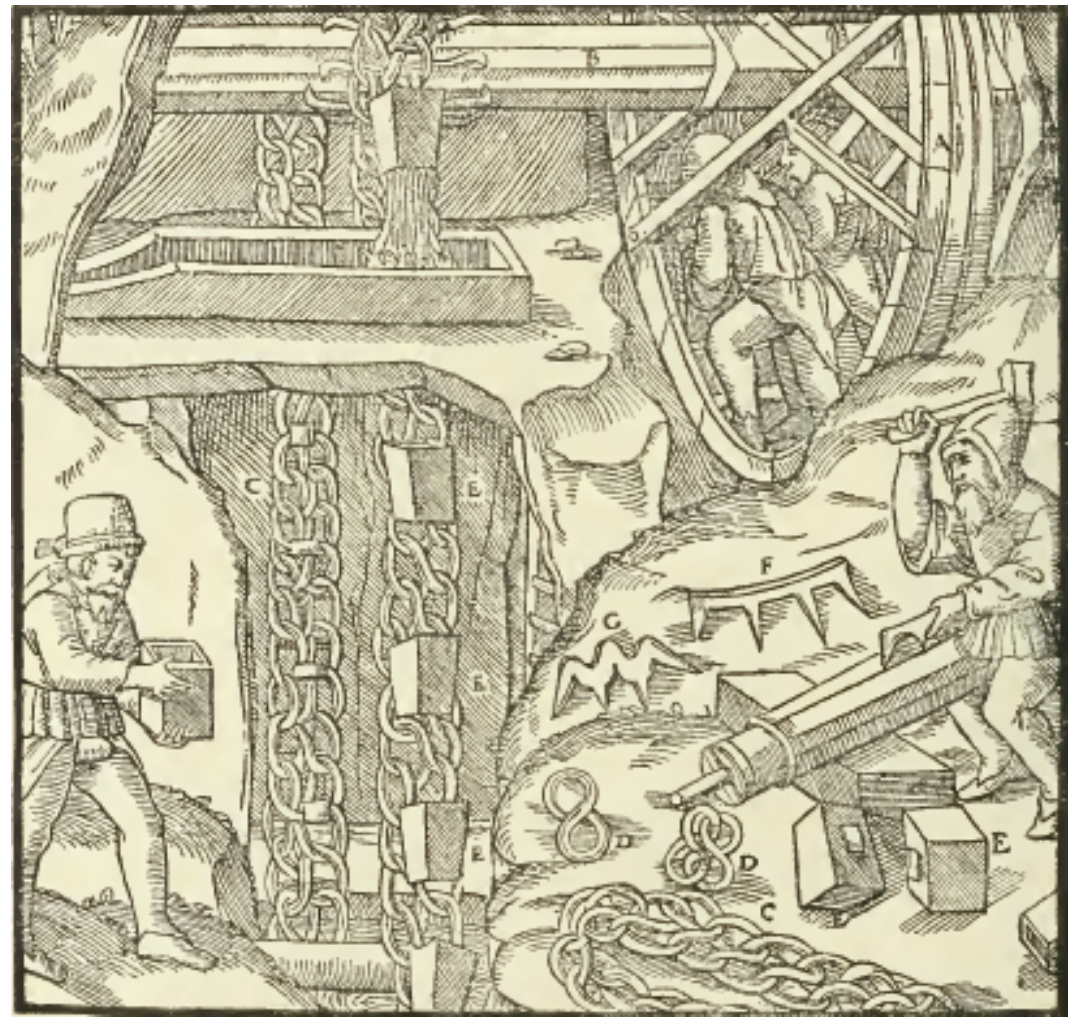

Figure 5. Machine with a bucket-chain. 
the water into a collection point in the tunnel (Figure 7). A wheel, set in motion by the flow of a river diverted from the mountain, raised and lowered the pistons of the three pumps simultaneously, thanks to a system of counter balances.

The interest in pumps and mills increased considerably in the second half of the $16^{\text {th }}$ century, driven not only by more obvious economic reasons, but also by

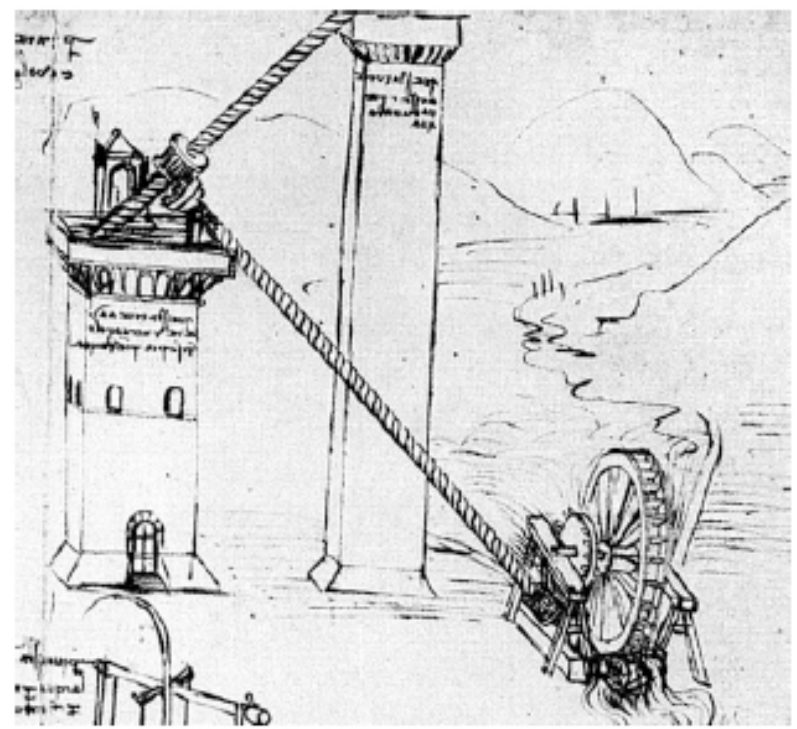

Figure 6. Leonardo da Vinci's double-screw pump.

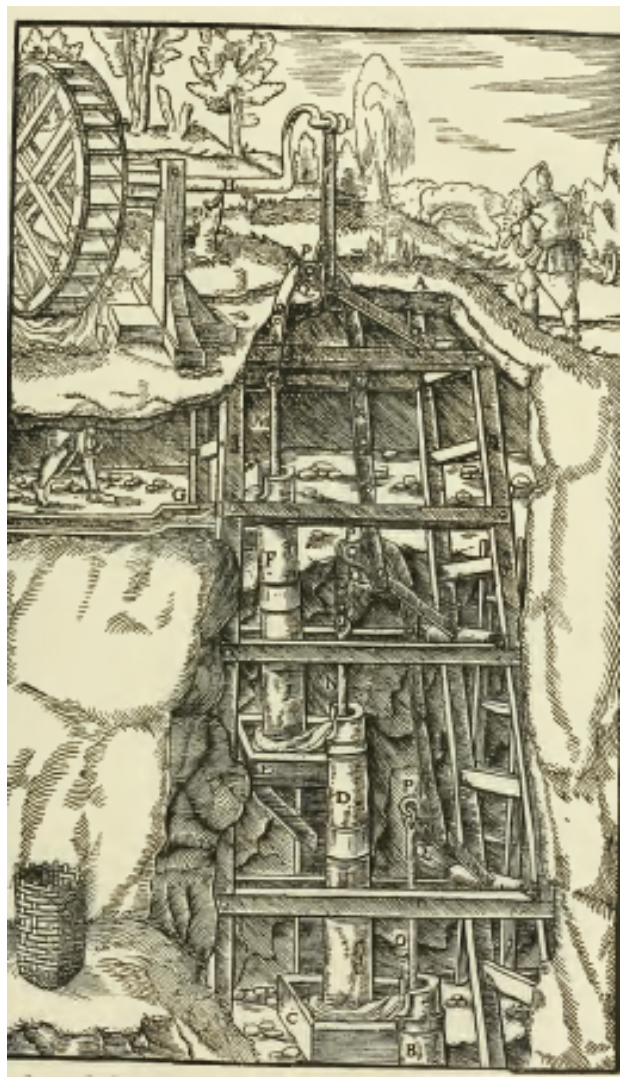

Figure 7. Suction machine with pumps in series. 
a sudden love for the fantastic, which found in Jacques Besson (1578) "the initiator of a new literary genre: the theatre of machines" (Marchis, 2005: p. 100). A clever combination of technology and imagination, and of theoretical descriptions and accurate didactic images, Besson's Theatrum instrumentorum soon became a sort of bestseller that appealed to numerous mathematicians and engineers of the time (Ceccarelli, 2004: pp. 288-289). These included the Frenchman Jean Errard, whose work Le Premier livre des instruments mathématiques et méchaniques, published in 1584, gave little space to water and wind power, preferring an innovative, counter-balance movement system, also in the design of pumps.

Another recurring theme in the albeit scarce literature on Renaissance water pumps concerned the possibility of obtaining a flow of water that was as constant as possible, i.e. not affected by the naturally alternating suction and expulsion of the liquid. Here too, Bélidor's writings offer interesting historical details: he recalled a pump model used in Holland that was equipped with perforated partitions for water purification and a leather diaphragm system to ensure greater water pressure.

A high-pressure pump similar to that described by Bélidor, i.e. fitted with diaphragms and capable of providing a continuous flow of water, even during the piston suction phase, was used in the most important royal libraries as an exceptional means of fire-fighting. In fact, already in 1615, the French engineer Salomon de Caus had described a similar machine, often used during fires, in his work on driving forces (Caus, 1615). The model described by de Caus (Figure 8), while having the advantage of operating with a single piston, not only required the combined efforts of more than one man to operate the pump, against a marked increase in mechanical efficiency due to the use of an upper opening smaller in size than the piston diameter, but remained, all things considered, one of the greatest "mechanical enigmas", the solution to which would not be found

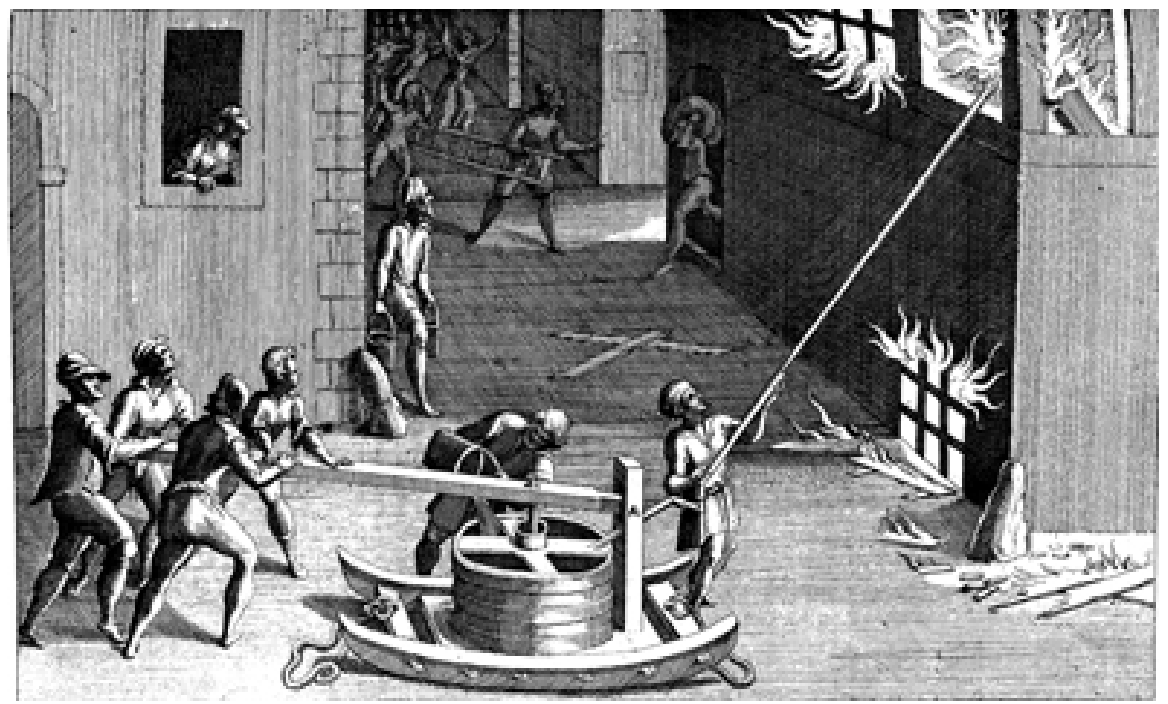

Figure 8. Continuous-flow pump described by de Caus. 
until 1725. That was the year in which an article was published in the Mémoires of the Parisian Academy of Sciences that revealed the secret of the continuous-flow piston pump and resolved the enigma, thanks to a discovery by the French chemist Charles François de Cisternay du Fay (Académie des sciences, 1725).

Having learned of the machine, whose inventor, Jacob Leupold, always kept its mechanism secret, du Fay managed to imitate the structure perfectly, obtaining the same result as the original, namely, the possibility of a constant flow of water without having to resort to a cumbersome double-piston structure. This result was obtained by using a spherical tank, into which a sufficient quantity of water was fed to cause the air inside it to compress. The water was forcefully expelled from a pipe positioned in the lower part of the tank. The action of a piston, together with a valve capable of allowing air or water to pass alternately, was sufficient to maintain the constant air pressure required for the forced expulsion of the water and to refill the water in the tank.

According to Bélidor, however, the idea of creating a continuous-flow pump could be traced further back in time, more precisely to the $1^{\text {st }}$ century AD, the time of Heron of Alexandria, who had applied the operating principle to ornamental fountains. Heron's machine consisted of two cylindrical vessels of the same size, both sealed at the ends and held together by an empty cylinder traversed by pipes, one going to the lower cylinder and the other to the upper one. The first allowed the water to descend and the second allowed the air to rise, causing the water to gush to the surface. There were holes near the base of the pipes, through which the rising air sucked water, causing it to gush to the top. The air, compressed by the water filling the lower cylinder, rose rapidly, causing a depression inside the pipe that sucked in more water and made it rise. As Bélidor explained, it was basically the effect of pressure (Bélidor, 1739: p. 192).

Also with regard to the combined effects of air and water, Bélidor described the operating principle-noting, however, that various models were used in machines-of the innovative system for blowing forced air into the fire in forges, provided there was an available source of water power, as in mountain areas. The machine worked with the exact opposite principle to Heron's fountain, as it harnessed the power of water to move the air (Figure 9).

Bélidor also provided the historical precedent for this machine, dating back this time to the $17^{\text {th }}$ century: in his essay on the motion of water, published posthumously in 1686, the French physicist and botanist Edme Mariotte described the bellows used at the time to melt metals in forges. It consists of a wooden pipe fixed to a container and a funnel, "into which water from some fountains [...] is made to cascade [...]; as the water falls, it takes with it a large quantity of air, which follows it down to the funnel [...]; a pipe is connected to the side of the vat that narrows gradually as it reaches the hole in the bottom of the furnace, from where the coal is blown; as the air is pushed and enclosed in the vat [...], it is forced to exit with great force from the end of the conduit" (Mariotte, 1686: p. 68). This 


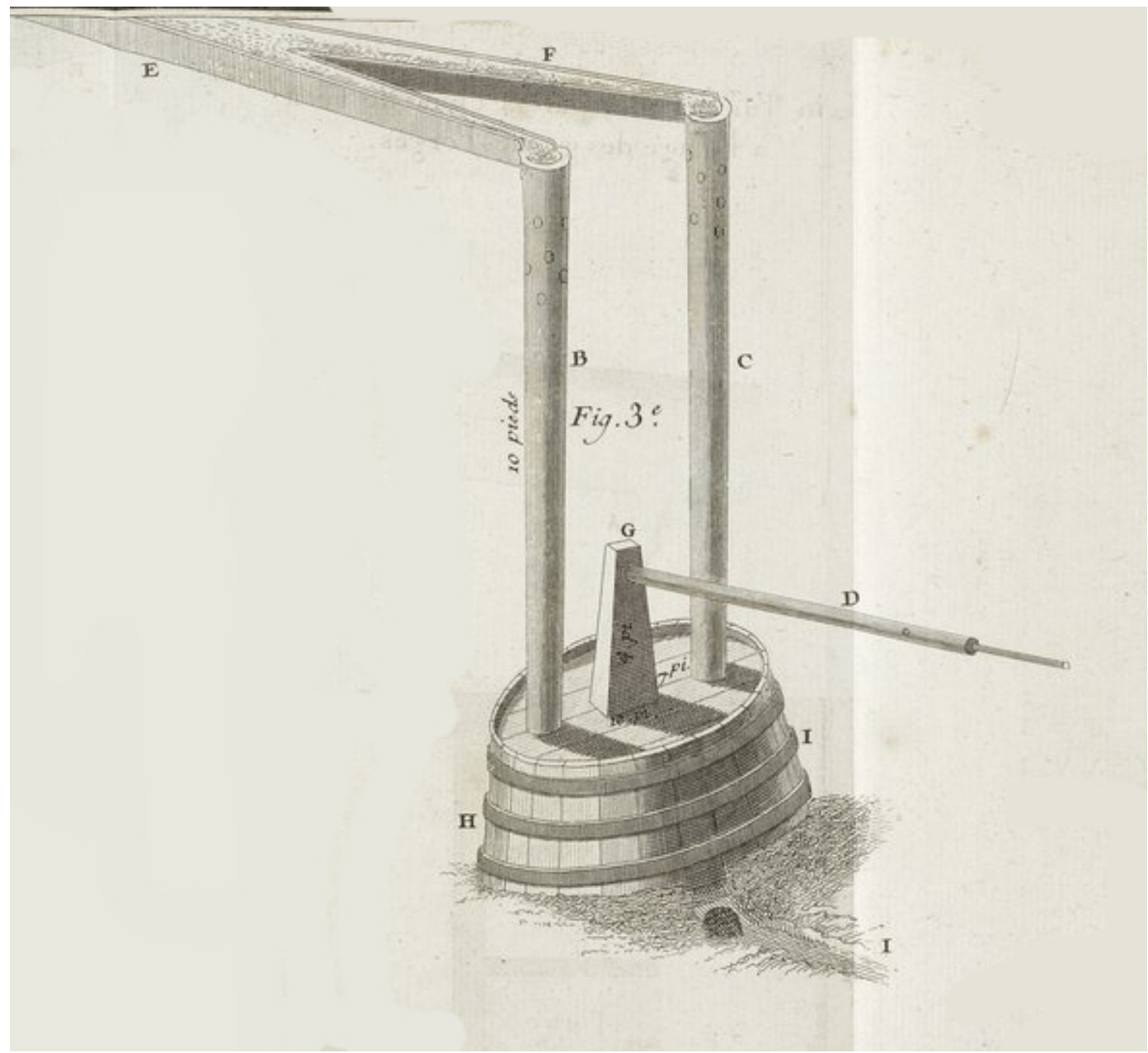

Figure 9. Machine to blow air into a forge.

system, Bélidor noted, was also used widely in Italy, particularly in the areas near Lake Garda and around Rome.

The machines for which Bélidor can be considered one of the greatest historiographers-although not the very first, as a brief description had already been edited in 1724 by Jacob Leupold (1724: pp. 61-62) - must certainly include the Marly machine. Completed in 1682 and inaugurated in 1684, after some years of work, it was commissioned by King Louis XIV to bring water from the Seine to the Palace of Versailles and the Château de Marly and regarded by many scholars as one of the world's greatest attractions. The Marly machine was, in fact, a complex system of pumps and intermediate reservoirs capable of raising water more than 150 metres above its source point (Figure 10).

The inventor and master carpenter from Liège, Rennequin Sualem, who oversaw the construction under the supervision of the French engineer Arnold de Ville, managed to build a system consisting of 14 wheels, 221 pumps, two intermediate reservoirs and a special bulkhead to prevent ice or wood carried by the river current from damaging the structure. A dam for the accumulation of water and an artificial canal for the passage of boats completed the monumental work. 


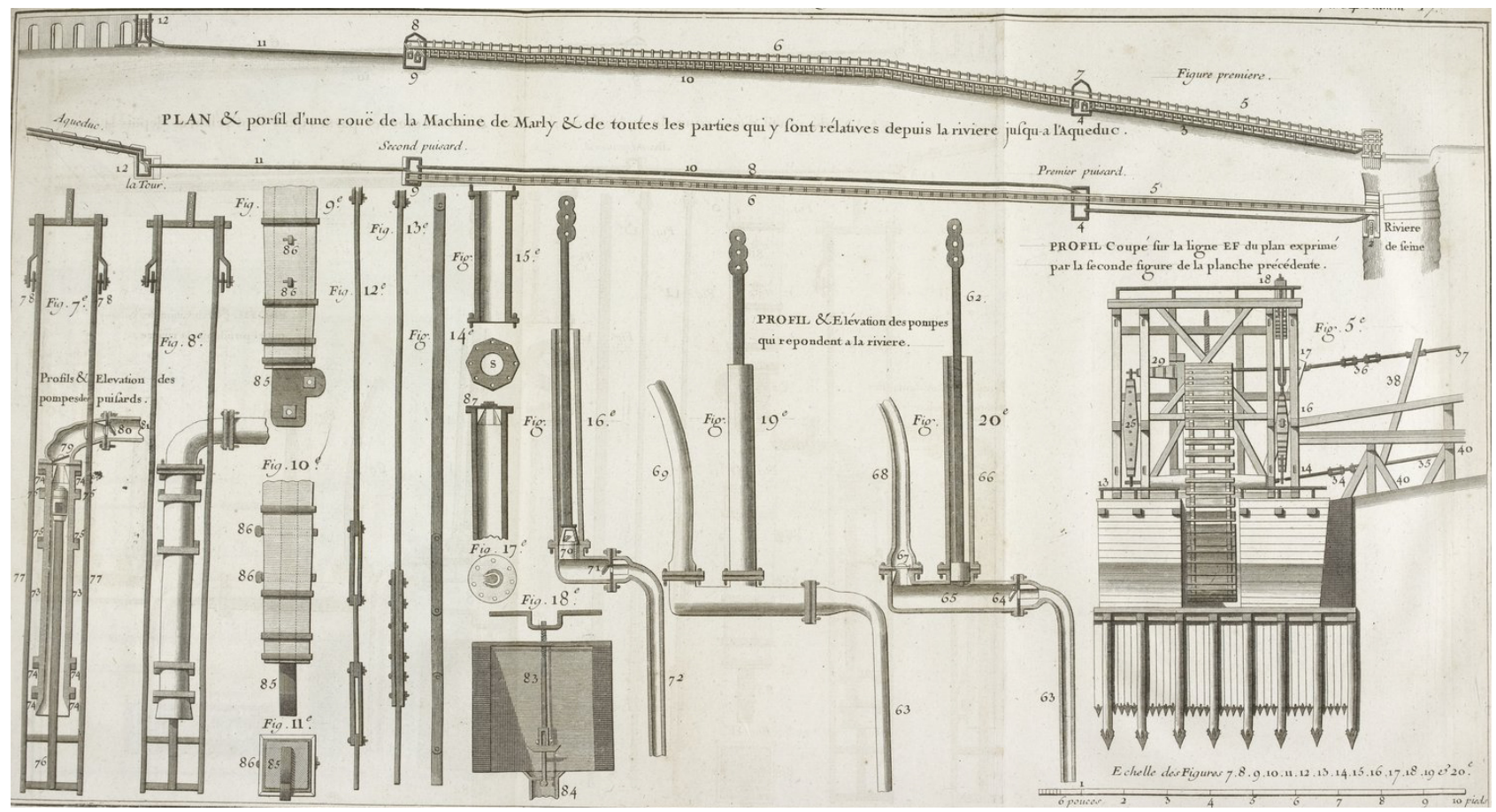

Figure 10. Functional diagram of the Marly Machine produced by Bélidor.

Bélidor said that he had received the plan and the drawings for the machine from a friend and had then personally verified their consistency, remaining on site for over a week, assisted by the indications of the machine controller, a certain Delespine (Bélidor, 1739: p. 196), who employed a force of sixty labourers working continuously.

The motion of each of the wheels in the Marly machine-which, according to Bélidor, was its main distinctive feature-produced two different effects, namely, it put into motion the pumps, which sucked water from the river and brought to the first reservoir, and the system of crossarm levers, which operated the second series of pumps, enabling the water to reach the second reservoir. From there, as can be seen in the first drawing in Figure 9, the water was sucked up to the tower and could then reach the aqueduct and flow to its destination, thanks to the slope of the structure.

In the Marly machine, in short, Bélidor saw the completion of the long history of the so-called "noria", the water wheel that Vitruvius dated back to a period before the time of Christ. Until the introduction of the steam engine, this still remained a privileged means of raising water, thanks to the flow of the watercourse. The water power was harnessed by some blades to drive the noria, which had a series of buckets attached to the perimeter of the wheel. As it turned continuously, the buckets would fill when immersed in the water and then empty their contents into a collection tank on their return to the top. The history of the noria, in fact, was not concluded until the 1820 s, about eighty years after its mention by Bélidor, when the French mechanic and inventor Louis Gateaux made a substantial modification to the machine to prevent the dispersion of water dur- 
ing unloading into the collection tank (Gateaux, 1820).

\section{Conclusion}

A great admirer of Roman aqueducts, Bélidor did not fail to retrace their history, relating it to the improvements made to them during the Middle Ages by the "people of Gaul" and the Parisians in particular (Bélidor, 1739: p. 206). The jewel in the crown, from this perspective, was the huge machine installed at the NotreDame bridge on the Seine, in 1670, composed of a large number of suction and pressure pumps capable of operating simultaneously to supply water to a large part of the capital. Also in this case, the driving force was provided by water power.

The history that Bélidor had meticulously reconstructed already tended to flow into the present. He was thinking specifically of the $18^{\text {th }}$ century when, in the introduction to the subsequent passage of his work, he wrote: "The ancients did not know the art of making machines move and made water and air work instead of men and horses, as we do today; but there is still an element to bring to the laws of mechanics: this was achieved in the first years of $18^{\text {th }}$ century, using fire" (ibid.: p. 308).

A new era was emerging in western technology and the mission of Bélidor, the historian, could be deemed concluded at that point, to make way, once more, for the engineer.

\section{Conflicts of Interest}

The author declares no conflicts of interest regarding the publication of this paper.

\section{References}

Académie des sciences (1725). Sur une pompe à éteindre les incendies. Histoire de l'Académie royale des sciences, avec ls Mémoires de mathématique, de physique, tirez des registres de cette Académie, 78-80.

Académie des sciences (1783). Éloge de M. de Bélidor. Histoire de l'Académie royale des sciences, avec les mémoires de mathématique, de physique, tirez des registres de cette Académie, 167-181.

Académie des sciences (1788). M. de Bélidor. Les illustres modernes, ou Tableau de la vie privée des principaux personnages des deux sexes, qui depuis la renaissance des lettres, ont acquis de la célébrité en Europe, tant en politique ou dans les armées que dans les arts, les sciences et la vie contemplative, 2, 64-66.

Agricola, G. (1556). De Re Metallica. Basileae: Froben \& Episcopius.

Bélidor (de), B. F. (1725). Nouveau cours de mathématique à l'usage de l'artillerie et du génie où l'on applique. Les Parties les plus utiles de cette Science à la Theorie et à la Pratique des differens sujets qui peuvent avoir rapport à la Guerre. Paris: Chez Nyon.

Bélidor (de), B. F. (1731). Le bombardier françois, ou nouvelle méthode de jetter les bombes avec precision. Paris: Imprimerie Royale.

Bélidor (de), B. F. (1737-1739). Architecture hydraulique ou l'art de conduire, d'élever et de ménager les aux pour les différentes besoins de la vie. Paris: Jombert. 
Beretta, M. (2017). Storia materiale della scienza. Dal libro ai laboratori, Roma: Carocci.

Besson, J. (1578). Teatrum instrumentorum et machinarum. Lugduni: Vincent. https://doi.org/10.5479/sil.269182.39088000339796

Caus (de), S. (1615). Les raisons des forces mouvantes, avec diverses machines tant utiles que plaisant. Frankfort: Norton. https://doi.org/10.5479/sil.375615.39088008194136

Ceccarelli, M. (2004). Historical Evolution of Classification of Mechanisms. In Proceedings of International Symposium on History of Machines and Mechanisms (pp. 285-302). Dordrecht: Springer. https://doi.org/10.1007/1-4020-2204-2_23

Gateaux, L. (1820). Mémoire sur une noria perfectionnée. Bulletin de la Société d'encouragement pour l'industrie nationale, 194, 277-281.

Leupold, J. (1724). Theatrum machinarum generale. Leipzig: Christoph Zunkel.

Marchis, V. (2005). Storia delle machine. Tre millenni di cultura tecnologica. Roma-Bari: Laterza.

Mariotte, E. (1686). Traité du mouvement des eaux et des autres corps fluids. Paris: Jombert.

Usher, A. P. (1957). Machines and Mechanisms. In C. Singer, E. J. Holmyard, A. Rupert Hall, \& T. I. Williams (Eds.), A History of Technology, vol. III From the Renaissance to the Industrial Revolution (pp. 324-346). Oxford: Clarendon Press.

Viollet, P.-L. (2005). Histoire de l'énergie hydraulique. Moulins, pompes, roués et turbines de l'Antiquité au $X X^{e}$ siècle. Paris: Presses de l'École Nationale des Ponts et chaussées. 